hepatic 25-hydroxylation of vitamin D and that alcohol, while having no effect on $25 \mathrm{OH} \mathrm{D}$ production in adult livers, inhibits synthesis in pup livers. Alcohol-mediated decreases in pup hepatic $25 \mathrm{OH} \mathrm{D}$ production as well as decreases in $25 \mathrm{OH} \mathrm{D}$ transport from mother to fetus (13) may contribute to the diminished $25 \mathrm{OH} \mathrm{D}$ content of alcohol-exposed vitamin Dreplete pups.

\section{REFERENCES}

1. Ponchon G, Kennan AL, DeLuca HF 1969 Activation of vitamin D by the liver. J Clin Invest 48:2032

2. Olson EB Jr, Knutson JC, Bhattacharyya MH, DeLuca HF 1976 The effect of hepatectomy on the synthesis of 25 hydroxyvitamin $\mathrm{D}_{3}$. J Clin Invest 57:1213

3. Ponchon G, Deluca HF 1979 The role of the liver in the metabolism of vitamin D. J Clin Invest 48:1273

4. Lund B. Sorenson OH, Hilden M, Lund B 1977 The hepatic conversion of vitamin $D$ in alcoholics with varying degrees of liver affection. Acta Med Scand 202:221

5. Posner DB, Russell RM, Absood S, Connor TB, Davis C, Martin L, Williams JB, Norris AH, Merchant C 1978 Effective 25 -hydroxylation of vitamin $\mathrm{D}_{2}$ in alcoholic cirrhosis. Gastroenterology 74:866

6. Barragry JM, Long RG, France MW, Wills MR, Boucher BJ, Sherlock S 1979 Intestinal absorption of cholecalciferol in alcoholic liver disease and primary biliary cirrhosis. Gut 20:559

7. Gascon-Barre M 1982 Plasma $25 \mathrm{OH}$ D response to a pharmacological dose of vitamin $\mathrm{D}$ or $25 \mathrm{OH} \mathrm{D}$ during chronic ethanol administration in the rat. Horm Metabol Res 14:332

8. Streissguth AP, Lundesman-Dwyer S, Martin JC, Smith DW 1980 Teratogenic effects of alcohol in humans and laboratory animals. Science 209:353

9. Baran DT 1983 Effect of chronic (8 week) phenobarbital treatment on the metabolism of ${ }^{3} \mathrm{H}$-vitamin $\mathrm{D}$ by the perfused rachitic rat liver in vitro. Am J Physiol 245:E55

10. Baran DT, Milne M $19831,25(\mathrm{OH})_{2} \mathrm{D}$ induced inhibition of ${ }^{3} \mathrm{H}-25 \mathrm{OH}$ D production by the rachitic rat liver in vitro. Calcif Tissue Int 35:461

11. Lowry OH, Rosebrough NJ, Farr AL, Randall RJ 1951 Protein measurement with the folin-phenol reagent. I Biol Chem 193:265

12. Haddad JG, Chyu KJ 1971 Competitive protein binding assay for 25 hydroxycholecalciferol. J Clin Endocrinol Metab 33:992

13. Baran DT 1982 Alcohol-induced inhibition of fetal ${ }^{3} \mathrm{H}-25 \mathrm{OH} \mathrm{D}$ and ${ }^{14} \mathrm{C}-\alpha-$ aminoisobutyric acid accumulation in the pregnant rat. Endocrinology 111:1109

14. Baran DT, Bryant C, Robson D 1982 Alcohol induced alterations in calcium metabolism in the pregnant rat. Am J Clin Nutr $36: 41$

15. Bell NH, Shaw S, Turner RT 1984 Evidence that 1,25 dihydroxy-vitamin D inhibits the hepatic production of 25 hydroxyvitamin $D$ in man. $J$ Clin Invest 74:1540

16. Lore F, DiCairano G, Periti P, Caniggia A 1982 Effect of the administration of 1,25 dihydroxyvitamin $\mathrm{D}_{3}$ on serum levels of 25 hydroxyvitamin $\mathrm{D}$ in postmenopausal osteoporosis. Calcif Tissue Int 34:539

17. Bhattacharyya MH, DeLuca HF 1974 Subcellular location of rat liver calciferol25-hydroxylase. Arch Biochem Biophys 160:58

18. Bjorkhem I, Holmberg I 1978 Assay and properties of a mitochondrial 25 hydroxylase active on vitamin D. J Biol Chem 253:842

19. Madhok TC, DeLuca HF 1979 Characteristics of the rat liver microsomal enzyme system converting cholecalciferol into 25 hydroxycholecalciferol. Biochem J 184:491

20. Bhattacharyya MH, DeLuca HF 1973 The regulation of rat liver calciferol-25hydroxylase. J Biol Chem 248:2969

21. Delvin EE, Arabian A, Glorieux FH 1978 Kinetics of liver microsomal cholecalciferol-25-hydroxylase in vitamin $\mathrm{D}$ deplete and replete rats. Biochem J 172:417

22. Bjorkhem I, Holmberg I, Oftebro H, Pedersen JI 1980 Properties of a reconstituted vitamin D-25-hydroxylase from rat liver mitochondria. J Biol Chem 255:5244

23. Halloran BP, Barthell EN, DeLuca HF 1979 Vitamin D metabolism during pregnancy and lactation in the rat. Proc Nat Acad Sci 76:5549

24. Baran DT, Milne M 1983 Inhibitory effect of calcium on ${ }^{3} \mathrm{H}-25 \mathrm{OH} D$ production by the rachitic rat liver in vitro. Clin Res 31:693 (abstr)

25. Ponappa BC, Waring AJ, Hoek JB, Rottenberg H, Rubin E 1982 Chronic ethanol ingestion increases calcium uptake and resistance to molecular disordering by ethanol in liver microsomes. J Biol Chem 257:10141

26. Brown NA, Goulding EH, Fabri S 1979 Ethanol embryotoxocity: direct effects on mammalian embryos in vitro. Science 206:573

\title{
Fatty Acid Abnormalities in Cystic Fibrosis
}

\author{
PHILIP M. FARRELL, ELAINE H. MISCHLER, MICHAEL J. ENGLE, D. JEANNETTE BROWN, \\ AND SZE-MEI LAU
}

Departments of Pediatrics and Nutritional Sciences, University of Wisconsin-Madison, Madison, Wisconsin 53792

\begin{abstract}
Fatty acids were measured by gas chromatography in lipid extracts of plasma and tissues obtained from three categories of $\mathbf{4 6}$ patients with cystic fibrosis. Low levels of the major essential fatty acid linoleate were found in plasma total lipids of patients who had malabsorption but not in those without evidence of steatorrhea. Circulating arachidonic acid was only slightly decreased, and the unusual triene reflecting pathologically altered fatty acid metabolism (20:3 $\omega 9)$ was generally not detected, nor was the triene/tetraene ratio abnormal except for in
\end{abstract}

Received February 1, 1984; accepted August 24, 1984

Address for correspondence and reprint requests Philip M. Farrell, M.D., Ph.D. H4/428 Clinical Sciences Center, University of Wisconsin-Madison, 600 Highland Avenue, Madison, WI 53792

This study was made possible by a research grant and a CTR Center grant from the Cystic Fibrosis Foundation. P.M.F. was supported by a Pulmonary SCOR grant from National Institutes of Health (P50-HL-27358). M.J.E. is the recipient of Research Career Development Award KD4-HD-00350. two patients. There was no correlation between plasma linoleate and age, clinical severity score, or vitamin $E$ status. Decreased linoleate did correlate with two indices of malabsorption, namely plasma carotene $(r=0.64)$ and fecal fat excretion $(r=0.76)$. Our data therefore indicate that the abnormality in linoleate is associated with (secondary to) malabsorption of dietary fat despite pancreatic enzyme replacement therapy and consumption of a regular diet. The frequency of this alteration was determined to be quite high in 40 patients with steatorrhea, $85 \%$ of whom showed values below the lower limit of normal for plasma linoleate. It was of interest to find markedly decreased levels of linoleate in adipose tissue, cardiac muscle, and lung and lesser reductions in liver and psoas muscle taken at autopsies. Tissue arachidonic acid percentage was normal, however, and $20: 3 \omega 9$ was rarely present. Thus, the physiological significance of this common abnormality in 
CF patients with malabsorption remains to be determined. (Pediatr Res 19: 104-109, 1985)

Abbreviations
EFA, essential fatty acid
CF, cystic fibrosis
PUFA, polyunsaturated fatty acid
TLC, thin layer chromatography

Previous investigations $(4,5,9,12,20-23,25,29,32)$ have revealed that patients with $\mathrm{CF}$ show low circulating levels of linoleic acid $(18: 2 \omega 6)$, an EFA which serves as a precursor for

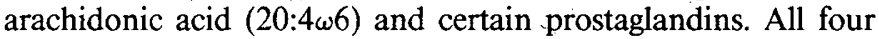
plasma lipid fractions (triglycerides, phospholipids, free fatty acids, and cholesterol esters) $(4,21)$ ánd erythrocytes $(20,29)$ are reportedly abnormal in $\mathrm{CF}$ patients with malabsorption. The significance of this abnormality and the consequences relative to the PUFA composition of tissues have not been elucidated. Furthermore, the frequency of abnormally low circulating 18:2 $\omega 6$ levels has not been established. There are many factors that potentially could cause or contribute to decreased linoleate, including: 1) malabsorption of ingested fat; 2) the traditional tendency of CF patients to restrict dietary fat consumption (10); 3) greater than normal utilization of dietary PUFA for energy production (19); 4) increased oxidation of PUFA due to associated vitamin $E$ deficiency; 5) faster turnover of fatty acids in CF leading to a greater than normal nutritional requirement; and 6) a metabolic defect in fatty acid metabolism (28). Of these possibilities, malabsorption of dietary fat has been implicated on the basis of results obtained from some studies $(12,21)$ of CF patients having apparently intact pancreatic function, i.e. those without steatorrhea. In one study, however, Hubbard et al. (21) found significantly reduced linoleate in the plasma triglyceride fraction of CF patients without evident pancreatic insufficiency and a mild but nonsignificant reduction in the phospholipid fraction. Also, Rogiers et al. $(30,31)$ reported moderately decreased linoleate in the free fatty acid and cholesterol ester fractions of plasma from CF patients with apparently intact pancreatic function. In addition, a recent abstract (7) mentioned three CF patients with no steatorrhea who had EFA "deficiency." Although low concentrations of linoleate have been reported in the membranes of isolated erythrocytes from CF patients (29), there has been no description to our knowledge of the fatty acid composition of vital organs in any children with malabsorption. The purpose of this investigation, therefore, was to assess further the fatty acid composition of circulating lipids and to determine if low levels of linoleate are present in adipose tissue and vital organs. Another objective was to evaluate the influence of vitamin E status on fatty acid abnormalities. Three groups of $\mathrm{CF}$ patients were evaluated: I-those with pancreatic insufficiency and vitamin $\mathrm{E}$ deficiency, II-those with pancreatic insufficiency who were supplemented with sufficient tocopherol to correct vitamin $\mathrm{E}$ deficiency, and III-six CF patients with normal fat absorption.

\section{METHODS}

Subjects. Patients with CF diagnosed by pilocarpine iontophoresis (35) who were visiting the University of Wisconsin Cystic Fibrosis Center for routine clinic evaluations were randomly chosen for this study as long as they were at least $2 \mathrm{~h}$ postprandial and gave informed consent for blood drawing. This project was approved by the University of Wisconsin Committee for the Protection of Human Subjects. Our clinic population was screened to identify three groups of patients, namely: I-those with vitamin E deficiency (as described below) and other evidence of malabsorption when not taking pancreatic enzyme supplements (i.e. presence of hypocarotenemia, gross steatorrhea, and an abnormal fat balance evaluation whenever studied); II-patients with malabsorption who were supplemented with $100-200$ IU of $\alpha$-tocopheryl acetate in a water miscible form (9); and III-patients with no evidence of steatorrhea, a normal vitamin $\mathrm{E}$ status without tocopherol supplements, and normal fecal fat excretion (26) and/or plasma carotene level. The age ranges of the three groups of patients and a normal group of healthy volunteers were similar; most patients were adolescents or young adults. Patients with pancreatic insufficiency were receiving supplements of pancreatic enzymes (generally Cotazym) with each meal. Although precise information was not available on the nutritional histories, most patients were apparently consuming a regular diet with $2 \%$ milk; none was taking supplements of medium-chain triglyceride oil.

CF patients with malabsorption who were not receiving supplements of vitamin E showed a total tocopherol concentration of $0.208 \pm 0.09 \mathrm{mg} / \mathrm{dl}$ that was less than the other three groups $(p<0.001)$. All patients in group I had a total tocopherol value less than the traditional lower limit of normal, namely $0.5 \mathrm{mg} /$ $\mathrm{dl}$ (11). Although this group and group II patients with malabsorption had total lipid values significantly less than normal, the tocopherol/total lipid ratio was reduced to $0.542 \pm 0.199(p<$ 0.001 , compared to normal mean \pm SD) in patients with malabsorption who were not receiving vitamin $E$ supplements. Using the critical ratio of 0.8 recommended by Horwitt $e t$ al. (18), it was found that 19 of 20 patients in group I were below this value while one subject has a ratio of 0.802 . In contrast, group II patients with malabsorption who were supplemented with 100 $200 \mathrm{IU} /$ day of vitamin $\mathrm{E}$ had a normal total tocopherol concentration $(0.873 \pm 0.372 \mathrm{mg} / \mathrm{dl})$ and a tocopherol/total lipid ratio $(2.25 \pm 1.07)$ which was higher $(p<0.01)$ than the normal group $(1.52 \pm 0.45)$. Each of these patients in group II showed a total tocopherol concentration at or above $0.5 \mathrm{mg} / \mathrm{dl}$ and all had a tocopherol/total lipid ratio above 0.8 . Although group III CF patients without malabsorption at $0.683 \pm 0.192 \mathrm{mg} / \mathrm{dl}$ were slightly below the mean plasma tocopherol concentration found in the normal group $(0.839 \pm 0.145 \mathrm{mg} / \mathrm{dl})$, these individuals showed no evidence of vitamin $E$ deficiency and exhibited a tocopherol/total lipid ratio $(1.40 \pm 0.41)$ similar to the normal group. Peroxide hemolysis tests confirmed the vitamin E status predicted from plasma tocopherol analyses in all the 36 subjects studied by these methods of assessing vitamin $E$ nutritional status. Ten patients of group I evaluated by the hemolysis test showed abnormal $(>5 \%$; mean $=47.1 \%)$ results while the 10 patients studied in group II and four patients so evaluated in group III, as well as 12 control subjects tested had normal peroxide hemolysis tests.

Chest radiographs were taken on patients with $\mathrm{CF}$ and evaluated by the method of Brasfield et al. (3) to generate disease severity scores. The radiographic scores were similar for groups I and II CF patients with malabsorption $(13.7 \pm 5.6$ and $11.9 \pm$ 4.9 , respectively). The patients without malabsorption, however, had a significantly higher score at $21.3 \pm 1.5(p<0.001)$, indicating less severe disease.

During the course of this study, autopsies were performed within $6-16 \mathrm{~h}$ postmortem on eight adolescent $\mathrm{CF}$ patients with malabsorption who died of chronic lung disease and cor pulmonale. One of these patients, after having had serial assessment of plasma fatty acids revealing low levels of EFA, was given an intravenous fat emulsion (Intralipid) providing $0.7 \mathrm{~g}$ of linoleate per $\mathrm{kg}$ body weight per day (7\% of caloric intake) for her last 4 wk. Five tissues (liver, lung, heart muscle, psoas muscle, and perirenal fat) were sampled from each autopsied patient and placed in a $-70^{\circ} \mathrm{C}$ freezer until biochemical analyses could be completed. It was not possible to procure tissues from an agematched group of normal control subjects during a 3-yr period concurrent with this study. For this reason, tissue fatty acid data were obtained from J. G. Bieri (NIAMDD, National Institutes of Health, Bethesda, MD) on six adults who died of various 
causes not related to malabsorption; these individuals have been previously described (1) with respect to linoleic and arachidonic acid composition; three died of acute vascular disorders and the others had cancer. We did obtain samples of the tissues of interest from two children who died suddenly in this hospital at $0.6 \mathrm{yr}$ of age due to Reye's syndrome (whose liver was not abnormal in fatty acid composition) and at $1.4 \mathrm{yr}$ because of laryngomalacia with cor pulmonale, heart failure, and a respiratory arrest. In addition, the National Diabetes Foundation recently sent us frozen samples of the above tissues taken within $6 \mathrm{~h}$ postmortem at autopsies of four "control" children who died unexpectedly in a state of good nutrition. These children were $0.4,1.7,10$, and $11 \mathrm{yr}$ of age and had congenital heart disease (first two patients), pyruvate dysmetabolism (with normal growth) leading to respiratory arrest, and asthma with acute respiratory failure. These autopsies yielded four to six sets of normal pediatric tissue specimens which were analyzed for fatty acid composition using procedures identical to those followed for the CF tissues.

Biochemical methods. Plasma samples were analyzed for total tocopherols using a previously described method (11) which also allows quantitation of the carotene concentration. Total lipids were determined by a modification (10) of the method of de La Heurga et al. (6) and the values obtained were used to calculate the ratio of total tocopherol to total lipids as recommended by Horwitt et al. (18). The susceptibility of 5\% suspensions of erythrocytes to hemolysis in the presence of $2 \%$ hydrogen peroxide was also assessed in approximately half the blood samples as a further index of vitamin E status (10).

For analysis of fatty acids, plasma total lipid extracts were routinely prepared by the method of Bligh and Dyer (2). Transesterification of total lipid was accomplished with $0.5 \mathrm{~N}$ methanolic $\mathrm{NaOH}$ and heating in a boiling water bath for 20 min, followed by addition of $\mathrm{BF}_{3}$-methanol and reheating; water was then added to stop the reaction. Methyl esters were twice extracted with petroleum ether. After concentration of the sample to $50-100 \mu \mathrm{l}$, a $2-\mu \mathrm{l}$ aliquot was injected into a 6 foot by $1 / 4$ inch glass column packed with Supelco GP-10\% SP-2330 on 100-120 mesh Chromosorb WAW. Gas chromatography was performed on a Hewlett-Packard 5830A instrument with a temperature program increasing from 185 to $212^{\circ} \mathrm{C}$ and with a nitrogen flow rate of $28 \mathrm{ml} / \mathrm{min}$. A flame ionization detector was used in conjunction with a calculating integrator for quantitation. Retention times were determined using standards purchased from Applied Science Laboratories and Supelco, Inc. One of the fatty acid methyl ester standards $(20: 3 \omega 9$ or 5,8,11-eicosatrienoic acid) was also analyzed by using a gas chromatography-mass spectroscopy to confirm its identity. The limit of detection for this fatty acid by our analytical system is $0.1 \%$.

Plasma lipid subfractions were also analyzed for fatty acid composition in six CF patients without malabsorption and six age- and sex-matched subjects from the normal group. Cholesterol esters, free fatty acids, triglycerides, and phospholipids were separated by TLC on silica gel G-25 plates using a solvent system of hexane/ether/glacial acetic acid $(70: 30: 1, \mathrm{v} / \mathrm{v} / \mathrm{v})$. The lipid fractions were visualized with iodine vapors and identified by comparison to authentic standards. The fractions were then scraped from the TLC plate into screw cap tubes, extracted with Bligh and Dyer (2) solution, concentrated, dried, and transesterified as described previously. Tissues obtained at autopsy were extracted for total lipids by the method of Radin (27). The final washed chloroform layer was dried under nitrogen, transesterified, and subjected to gas chromatography to evaluate the fatty acid composition.

All results presented are as mean $\pm \mathrm{SD}$ values. Data were analyzed statistically by the unpaired $t$ test to compare differences of means. In addition, an analysis of variance was performed using the Fisher least significant difference approach applied for pairwise comparisons as described by Winer (34). A probability level of 0.01 was utilized as the $\alpha$ (type I error) value required for statistical significance.

\section{RESULTS}

The fatty acid compositions of plasma total lipid extracts are shown in Table 1 for the four groups of individuals. It was found that the percentages of linoleic acid were decreased in both groups of $\mathrm{CF}$ patients with malabsorption, while significant increases were noted in palmitate, palmitoleate, and oleate. No differences could be attributed to vitamin E status, however, since the fatty acid abnormalities were similar in groups I and II. The fatty acid composition of lipid extracts prepared from plasma samples of $\mathrm{CF}$ patients without malabsorption were indistinguishable from the normal group except for a slightly higher level of oleic acid, as shown in Table 1. A correlation was found between plasma carotene concentration and percentage linoleic acid for the total CF patient population studied $(\mathrm{r}=0.64 ; p<0.001)$. In addition, examining the percentage of dietary fat absorbed in relationship to plasma linoleic acid level in 16 patients concurrently assessed also revealed a correlation $(\mathrm{r}=0.76 ; p<0.001)$. The significantly low percentage of the major EFA linoleate detected on fatty acid compositional analysis of plasma was even more impressive when a calculation was made relative to the absolute concentrations of total plasma lipids. This revealed that group I had an estimated average plasma linoleate of $74.9 \mathrm{mg} / \mathrm{dl}$ and group II showed $88.6 \mathrm{mg} / \mathrm{dl}$, while the normal group had a mean value of $207 \mathrm{mg} / \mathrm{dl}$ and group III CF patients without malabsorption were normal at $194 \mathrm{mg} / \mathrm{dl}$. In addition to low plasma concentrations of linoleate, nine $\mathrm{CF}$ patients of groups I and II had detectable levels of $20: 3 \omega 9$, while none was found in the plasma extracts from groups III or IV. Only two CF patients, however, had triene/tetraene ratios above the level $(0.2)$ considered biochemically diagnostic of EFA deficiency (17).

Table 2 presents data obtained from fatty acid analysis of lipid fractions isolated by TLC from plasma of either CF patients without malabsorption or normal subjects. There was only one statistically significant difference, namely a slightly lower percentage of linoleate in the phospholipid fraction of group III CF patients. There was considerable overlap, however, in percentage fatty acid values measured in the phospholipid fraction such that half the CF patients had linoleate levels within the $95 \%$ confidence interval of the normal subgroup.

Fatty acid compositions of tissues obtained at autopsy from CF patients and groups of apparently well-nourished adults and children are described in Table 3 . It was of interest to find that the pediatric tissues except for lung showed $60 \%$ more linoleate than the adults, while oleate levels were lower in children. As expected because of the contribution of surfactant phospholipids (33), lung in each autopsy group showed relatively greater palmitate than the other tissues (data not shown). When compared to the two contrast groups without malabsorption, seven $C F$ patients with histologically proven severe pancreatic disease had significant reductions in the percentage of linoleic acid found in adipose tissue, cardiac muscle, and lung. Linoleate levels were also low in CF liver $(p<0.001)$ and psoas muscle $(p<0.005)$ compared to the pediatric normals. Arachidonic acid concentrations in the five sets of CF specimens were not significantly different from the normal groups, nor were any differences generally evident in the major monounsaturated fatty acids, palmitoleate and oleate. The pathologic triene 20:3 $\omega 9$ was found in six of seven CF liver specimens. Although this finding was unique to the CF group, the amount of $20: 3 \omega 9$ only averaged $0.3 \%$ and in no case was there a high triene/tetraene ratio (1517). The patient with the most abnormal plasma triene/tetraene ratio $(0.56)$ showed the greatest reductions in linoleate with less than half the normal percentage found in all tissues except heart muscle. All organs evaluated in this individual had readily detectable levels of $20: 3 \omega 9$, averaging $0.4 \%$. The other patient with triene/tetraene ratio above 0.2 received Intralipid before death and showed tissue fatty acid levels distinctly different from the other patients. As illustrated in Figure 1, the percentages of linoleate in this 18 -yr-old patient's tissues were not only higher 
Table 1. Percentage fatty acid composition of plasma total lipid extracts of patients with CF and normal subjects

\begin{tabular}{lccccc}
\hline \multicolumn{1}{c}{ Group } & $\begin{array}{c}\text { Palmitate } \\
(16: 0)\end{array}$ & $\begin{array}{c}\text { Palmitoleate } \\
(16: 1)\end{array}$ & $\begin{array}{c}\text { Oleate } \\
(18: 1)\end{array}$ & $\begin{array}{c}\text { Linoleate } \\
(18: 2 \omega 6)\end{array}$ & $\begin{array}{c}\text { Arachidonate } \\
(20: 4 \omega 6)\end{array}$ \\
\hline $\begin{array}{l}\text { I-CF with malabsorption and vi- } \\
\text { tamin E deficiency }\end{array}$ & $23.8 \pm 1.82^{*}$ & $6.31 \pm 1.44^{*}$ & $29.8 \pm 3.64^{*}$ & $19.7 \pm 4.66^{*}$ & $6.87 \pm 1.55$ \\
II-CF with malabsorption, sup- & $22.7 \pm 1.85^{*}$ & $5.79 \pm 1.96^{*}$ & $29.9 \pm 3.03^{*}$ & $20.5 \pm 5.18^{*}$ & $6.71 \pm 1.93$ \\
$\quad$ plemented with vitamin E & & & & \\
III-CF without malabsorption & $20.9 \pm 2.25$ & $3.20 \pm 0.51$ & $23.9 \pm 2.55 \dagger$ & $31.2 \pm 2.30$ & $7.88 \pm 2.42$ \\
IV-Normal & $20.0 \pm 1.43$ & $2.70 \pm 0.67$ & $21.1 \pm 2.32$ & $34.7 \pm 3.98$ & $7.91 \pm 1.23$ \\
\hline
\end{tabular}

$* p<0.001$ compared to normal group.

$\dagger p<0.02$ compared to normal group.

Table 2. Fatty acid composition of lipid fractions isolated from plasma of CF patients without malabsorption and normal subjects

\begin{tabular}{|c|c|c|c|c|c|c|}
\hline Group & Lipid fraction & $\begin{array}{c}\text { Palmitate } \\
(16: 0)\end{array}$ & $\begin{array}{c}\text { Palmitoleate } \\
(16: 1)\end{array}$ & $\begin{array}{l}\text { Oleate } \\
(18: 1)\end{array}$ & $\begin{array}{l}\text { Linoleate } \\
(18: 2 \omega 6)\end{array}$ & $\begin{array}{c}\text { Arachidonate } \\
(20: 4 \omega 6)\end{array}$ \\
\hline & Phospholipids & & & & & \\
\hline $\mathrm{CF}^{*}$ & & $31.5 \pm 4.44$ & $1.49 \pm 0.23$ & $15.9 \pm 1.67$ & $20.0 \pm 1.63 \dagger$ & $7.59 \pm 1.59$ \\
\hline \multirow[t]{2}{*}{ Normal $\ddagger$} & & $28.6 \pm 2.47$ & $1.29 \pm 0.17$ & $14.2 \pm 1.44$ & $23.1 \pm 1.63$ & $7.64 \pm 1.08$ \\
\hline & Triglycerides & & & & & \\
\hline $\mathrm{CF}$ & & $27.5 \pm 3.41$ & $5.38 \pm 0.64$ & $41.0 \pm 2.69$ & $12.7 \pm 3.46$ & $0.64 \pm 0.36$ \\
\hline \multirow[t]{2}{*}{ Normal } & & $27.6 \pm 2.59$ & $5.24 \pm 0.41$ & $41.2 \pm 3.61$ & $12.6 \pm 3.10$ & $0.98 \pm 0.59$ \\
\hline & Cholesterol Esters & & & & & \\
\hline $\mathrm{CF}$ & & $15.4 \pm 1.74$ & $5.48 \pm 1.52$ & $25.9 \pm 3.75$ & $45.6 \pm 5.45$ & $3.57 \pm 1.20$ \\
\hline \multirow[t]{2}{*}{ Normal } & & $14.4 \pm 0.94$ & $4.48 \pm 0.99$ & $22.7 \pm 1.48$ & $50.7 \pm 3.10$ & $4.00 \pm 0.64$ \\
\hline & FFA & & & & & \\
\hline $\mathrm{CF}$ & & $25.6 \pm 4.18$ & $4.01 \pm 1.15$ & $34.7 \pm 7.95$ & $12.2 \pm 2.34$ & $0.42 \pm 0.41$ \\
\hline Normal & & $27.7 \pm 4.72$ & $4.43 \pm 1.16$ & $35.2 \pm 8.55$ & $11.9 \pm 3.56$ & $0.10 \pm 0.11$ \\
\hline
\end{tabular}

* The cystic fibrosis group consisted of six patients (two male, four female) averaging $18.3 \pm 8.5 \mathrm{yr}$ of age.

$\dagger p<0.01$ compared to normal group; no other significant differences.

$\ddagger$ The normal group consisted of six subjects (two male, four female) averaging $18.8 \pm 7.5 \mathrm{yr}$ of age.

Table 3. Fatty acid composition of tissues obtained at autopsy from seven adolescent CF patients with malabsorption compared to

\begin{tabular}{|c|c|c|c|c|}
\hline Tissue group & $\begin{array}{c}\text { Palmitoleate } \\
(16: 1)\end{array}$ & $\begin{array}{l}\text { Oleate } \\
(18: 1)\end{array}$ & $\begin{array}{l}\text { Linoleate } \\
(18: 2 \omega 6)\end{array}$ & $\begin{array}{c}\text { Arachidonate } \\
(20: 4 \omega 6)\end{array}$ \\
\hline \multicolumn{5}{|l|}{ Fat } \\
\hline $\mathrm{CF}$ & $9.18 \pm 2.43$ & $46.2 \pm 2.10$ & $7.76 \pm 2.90^{*}$ & $0.40 \pm 0.16$ \\
\hline Adult normal & $4.13 \pm 1.25$ & $49.4 \pm 4.60$ & $13.8 \pm 3.48$ & $0.48 \pm 0.33$ \\
\hline Pediatric normal & $5.60 \pm 2.37$ & $37.6 \pm 8.12$ & $21.9 \pm 8.84$ & $0.45 \pm 0.14$ \\
\hline \multicolumn{5}{|l|}{ Psoas muscle } \\
\hline $\mathrm{CF}$ & $6.98 \pm 2.47$ & $34.9 \pm 6.72$ & $11.3 \pm 5.25 \dagger$ & $5.05 \pm 2.82$ \\
\hline Adult normal & $5.16 \pm 3.39$ & $42.3 \pm 2.91$ & $15.9 \pm 3.18$ & $2.84 \pm 1.42$ \\
\hline Pediatric normal & $3.40 \pm 1.23$ & $24.7 \pm 4.33$ & $26.1 \pm 5.59$ & $7.09 \pm 2.05$ \\
\hline \multicolumn{5}{|l|}{ Heart muscle } \\
\hline $\mathrm{CF}$ & $5.89 \pm 4.23$ & $30.2 \pm 9.42$ & $11.7 \pm 4.59 \dagger$ & $12.6 \pm 5.99$ \\
\hline Adult normal & $1.60 \pm 0.68$ & $24.5 \pm 5.32$ & $17.4 \pm 2.01$ & $15.8 \pm 4.12$ \\
\hline Pediatric normal & $1.83 \pm 1.01$ & $19.7 \pm 5.43$ & $25.5 \pm 5.77$ & $15.6 \pm 12.0$ \\
\hline \multicolumn{5}{|l|}{ Liver } \\
\hline $\mathrm{CF}$ & $7.02 \pm 1.69$ & $37.1 \pm 7.82$ & $8.55 \pm 3.72 \ddagger$ & $4.80 \pm 3.11$ \\
\hline Adult normal & $5.05 \pm 2.38$ & $38.6 \pm 6.54$ & $12.6 \pm 3.66$ & $3.15 \pm 2.82$ \\
\hline Pediatric normal & $4.44 \pm 1.47$ & $25.3 \pm 3.94$ & $20.4 \pm 8.71$ & $6.89 \pm 3.13$ \\
\hline \multicolumn{5}{|l|}{ Lung } \\
\hline $\mathrm{CF}$ & $6.60 \pm 1.59 \dagger \S$ & $29.0 \pm 9.21$ & $5.02 \pm 1.56 \|$ & $10.2 \pm 3.58$ \\
\hline Adult normal & $3.04 \pm 0.96$ & $27.2 \pm 4.99$ & $11.4 \pm 1.82$ & $10.5 \pm 2.11$ \\
\hline Pediatric normal & $2.81 \pm 1.6$ & $20.3 \pm 3.83$ & $13.4 \pm 4.25$ & $12.6 \pm 1.74$ \\
\hline
\end{tabular}

${ }^{*} p<0.01$, compared to the normal groups.

$\dagger p<0.005$, compared to the pediatric normal group.

$\ddagger p<0.001$, compared to the pediatric normal group.

$\S p<0.005$, compared to the adult normal group.

$\| p<0.001$, compared to the normal groups.

than those of the other six CF patients, but generally were greater than 1 SD above the adult normal mean. She also had a completely normal plasma fatty acid composition at the time of death despite being markedly low in plasma linoleate when the intravenous fat emulsion was started (Table 4).

\section{DISCUSSION}

Our observations on specific plasma fatty acid abnormalities in malabsorption due to cystic fibrosis are generally in agreement with data reported by others $(4,5,9,12,20-23,25,29,32)$. 
Although the true frequency of the major change, namely low plasma linoleate, has been uncertain, results from this investigation of $40 \mathrm{CF}$ patients with malabsorption indicate that $85 \%$ of the subjects in groups I and II were below the mean -2 SD value for plasma linoleate. In contrast, none of the controls or CF patients with presumably satisfactory pancreatic function (group III) were below this discriminating value of $26 \%$ linoleate in the total lipid extract. It should be emphasized, however, that the CF patients without clinically evident malabsorption (group III) had a significantly better mean clinical score than groups I and II. This observation confirms a recent report (13) associating a milder course of pulmonary disease to "intact" pancreatic function.

Thus, it is clear that most CF patients with malabsorption have low levels of this EFA in their circulating pool of lipids, despite the reduction of steatorrhea by consumption of pancreatic enzymes with meals. It is equally clear that the linoleate abnormality in CF is associated particularly with malabsorption, although subnormal fat intake might also play a role. Our results revealed a correlation between indices of steatorrhea and the

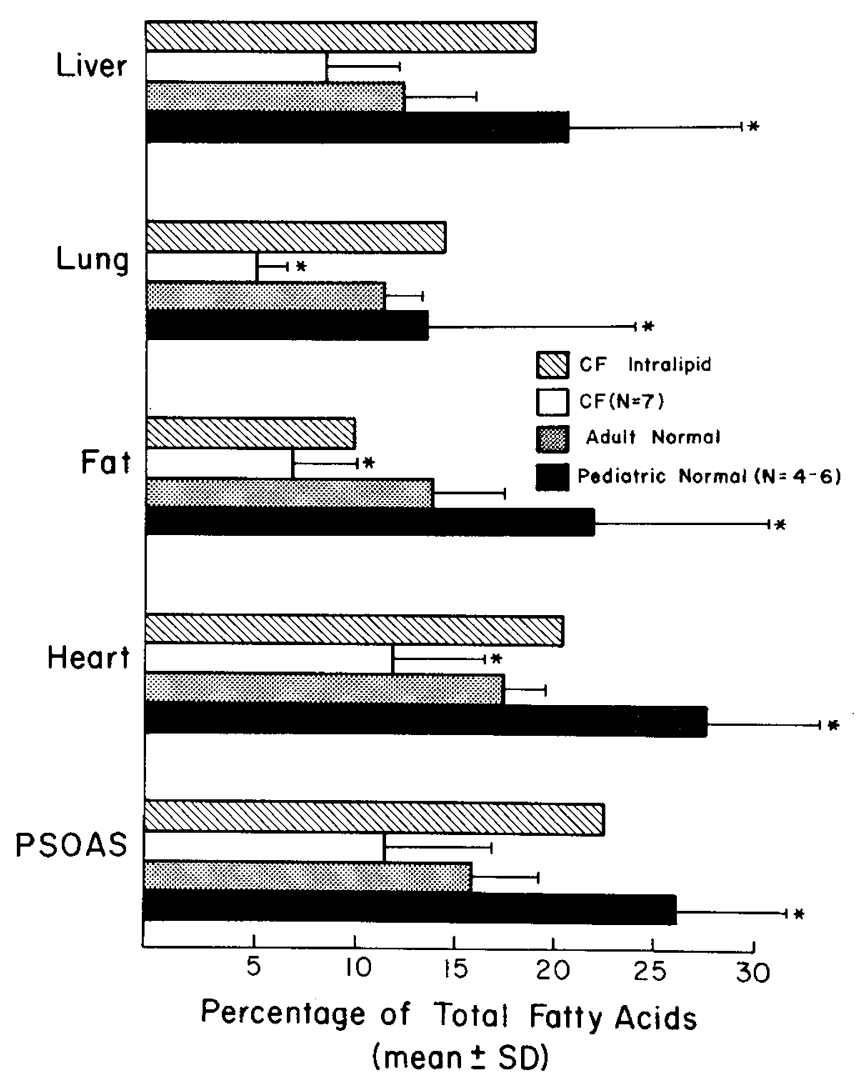

Fig. 1. Tissue linoleate levels in CF. Mean values shown with SDs indicated by brackets represent the percentage of linoleate in fatty acid methyl esters prepared from total lipid extracts. Asterisks indicate differences that are statistically significant compared to the $\mathrm{CF}$ group. The $\mathrm{CF}$ patient given Intralipid received $0.7 \mathrm{~g}$ of linoleate per $\mathrm{kg}$ body weight per day for $4 \mathrm{wk}$ prior to death. See the text for further information. concentration of linoleate in total plasma lipid, whereas no association could be made with age or clinical score reflecting pulmonary disease. Our data also indicate conclusively that vitamin E deficiency, despite the potential increase in PUFA oxidation, is not the underlying factor in the altered linoleate status. As pointed out by Hubbard (19), however, it is possible that increased utilization of PUFA for energy production might be a contributing factor to the low linoleate levels, especially in patients with inadequate caloric intake. This might explain in part the normal fatty acid status of CF patients with mild disease in group III.

The generally normal levels of linoleate in plasma lipid fractions of CF patients without steatorrhea, as noted in this study and by some $(12,21)$ but not all $(31)$ previous investigators, argues against EFA deficiency being a primary metabolic disturbance in $\mathrm{CF}$, as originally proposed by Rivers and Hassam (28). Rogiers et al. (31) recently pointed out that the percentage linoleate in plasma cholesterol esters might be a sensitive indicator of EFA status since this fatty acid accounts for approximately half the total acyl content of this fraction. Although their data indicated a significant reduction from $56.1 \%$ (normal mean) to $49.1 \%$ in $\mathrm{CF}$ patients without pancreatic insufficiency, we (Table 2) and Hubbard et al. (21) found statistically unaltered linoleate levels in the cholesterol ester fraction. It should be mentioned, however, that the phospholipid fraction of CF patients without clinically evident malabsorption did show a slight, statistically significant reduction in linoleate. Because recent dietary history has little effect on the fatty acid composition of circulating phospholipids (in contrast to triglycerides) and since this group consumed a normal diet, it is unlikely that nutritional factors account for the difference observed. On the other hand, it is possible that some of the six patients in group III had subclinical pancreatic insufficiency (24) which over a period of time might lead to low levels of linoleate in the phospholipid fraction. This would be in keeping with recent observations of Durie et al. (7).

The question arises as to the physiologic significance of the fatty acid abnormalities that occur in CF patients with malabsorption. An indication of pathologically altered fatty acid metabolism may be obtained by evaluating levels of $20: 3 \omega 9$, the unusual triene synthesized from oleic acid in severe EFA deficiency which causes the triene/tetraene ratio (15-17) to become high enough to establish the diagnosis unequivocally. Because only nine of $40 \mathrm{CF}$ patients with malabsorption had detectable levels of this triene and only two patients had plasma triene/ tetraene ratios above $0.2(12)$, it would appear that in general the linoleate deficiency is not sufficiently severe to have a major impact on fatty acid metabolism. It was of interest to find in tissue analyses that linoleate levels were significantly decreased in perirenal fat, heart muscle, and lung while being low but not statistically different from adult normal values in psoas muscle and liver. Nevertheless, arachidonic acid levels were not altered in any of these tissues. Furthermore, the pathologic triene was generally only present in low concentrations in liver and not to the extent found in animals with the characteristic features of EFA deficiency (16). Thus, high triene/tetraene ratios were not found in any CF tissue. Even the patient with a triene/tetraene ratio of 0.56 in plasma did not show an impressive alteration in the vital organs analyzed. In a previous study of adipose tissue

Table 4. Plasma fatty acid profile in an 18-yr-old CF patient supplemented with $1.3 \mathrm{~g}$ Intralipid/kg/day

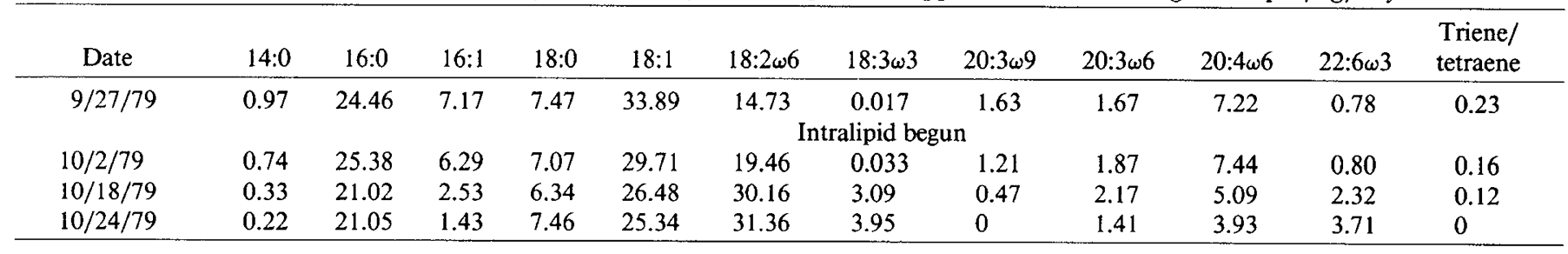


biopsy specimens, Kuo et al. (22) found low linoleate levels but did not comment on triene/tetraene ratios.

In view of these observations, we conclude that the physiologic significance of low linoleic acid concentrations in blood and tissues of $\mathrm{CF}$ patients with malabsorption remains to be delineated. It is quite unlikely that changes in fatty acid-related lung functions occur in CF patients as have been reported in EFAdeficient animals with a much greater severity of deficiency due to dietary alterations (23). On the other hand, it is possible that a subtle alteration could occur in cellular metabolism or in the phospholipid components of membranes that would lead to significant functional disturbances as some have postulated $(8$, 14). Because of the fact that low levels of linoleate occur commonly in CF patients in association with steatorrhea, it must be concluded that such patients are often biochemically malnourished (10) with respect to this essential nutrient. Elucidation of the role of linoleate deficiency in $C F$ will require longitudinal evaluation of patients with malabsorption studied comprehensively in a randomized clinical trial involving successful linoleate supplementation to correct the abnormality.

Acknowledgments. We thank the National Diabetes Research Interchange and Drs. Sunita Arya, Enid Gilbert, and William Perloff for their assistance in obtaining autopsy specimens. We also thank Dr. Mari Palta for biostatistical advice.

\section{REFERENCES}

1. Bieri JG, Evarts RP 1975 Tocopherols and polyunsaturated fatty acids in human tissues. Am J Clin Nutr 28:717

2. Bligh EG, Dyer WJ 1959 A rapid method of total lipid extraction and purification. Can J Biochem Physiol 37:911

3. Brasfield D, Hicks G, Soong SJ, Tiller RE 1979 The chest roentgenogram in cystic fibrosis: A new scoring system. Pediatrics 63:24

4. Caren R, Corbo L 1966 Plasma fatty acids in pancreatic cystic fibrosis and liver disease. J Clin Endocrinol 26:470

5. Chase HP, Dupont J 1978 Abnormal levels of prostaglandins and fatty acids in blood of children with cystic fibrosis. Lancet $2: 236$

6. de La Huerga JC, Wesinick C, Popper H 1953 Estimation of total serum lipids by a turbidimetric method. Am J Clin Pathol 23:1163

7. Durie PR, Gaskin KJ, Kopelman HR, Corey M, Forstner GG, Heim T 1983 Correlation between plasma fatty acid composition and pancreatic function in cystic fibrosis (Abstract). Pediatr Res 17:186A

8. Elliott RB 1972 The effect of essential fatty acids on sweat sodium concentrations in cystic fibrosis. Aust Paediatr J 8:217 (abstr)

9. Farrell PM, Bieri JG, Fratantoni JF, et al. 1977 The occurrence and effects of human vitamin $\mathrm{E}$ deficiency: A study in patients with cystic fibrosis. J Clin Invest 60:233

10. Farrell PM, Hubbard V 1983 Nutrition in cystic fibrosis: Vitamins, fatty acids, and minerals. In Lloyd-Still JD (ed) Textbook of Cystic Fibrosis. John Wright, PSG Inc, Boston, pp 263-292

11. Farrell PM, Levine S, Murphy LL, et al. 1978 Plasma tocopherol levels and tocopherol-lipid relationships in a normal population of children as com- pared to healthy adults. Am J Clin Nutr 31:1720

12. Galabert C, Filliat M, Chazalette JP 1978 Fatty acid composition of serumlecithins in cystic fibrosis patients without steatorrhea. Lancet 2:903

13. Gaskin K, Gurwitz D, Durey P, et al. 1982 Improved respiratory prognosis in patients with cystic fibrosis with normal fat absorption. J Pediatr 100:857

14. Harper TB, Chase HP, Henson J, Henson PM 1982 Essential fatty acid deficiency in the rabbit as a model of nutritional impairment in cystic fibrosis. Am Rev Respir Dis 126:540

15. Holman R 1968 Essential fatty acid deficiency. Prog Chem Fats Other Lipid 9:275

6. Holman RT 1968 The ratio of trienoic:tetraenoic acids in tissue lipids as a measure of essential fatty acid requirement. J Nutr 70:405

17. Holman RT, Smythe L, Johnson S 1979 Effect of sex and age on fatty acid composition of human serum lipids. J Clin Nutr 32:2390

18. Horwitt MK, Harvey CC, Dahm CH, Searcy MT 1972 Relationship between tocopherol and serum lipid levels for determination of nutritional adequacy. Ann NY Acad Sci 203:223

19. Hubbard V 1983 What is the association of essential fatty acid status with cystic fibrosis. Eur J Pediatr 141:68

20. Hubbard VS, Dunn GD 1980 Fatty acid composition of erythrocyte phospholipids from patients with cystic fibrosis. Clin Chim Acta 102:115

21. Hubbard VS, Dunn GD, di Sant'Agnese PA 1977 Abnormal fatty-acid composition of plasma-lipids in cystic fibrosis: a primary or secondary defect? Lancet 2:1302

22. Kuo PY, Huang NN, Bassett DR 1962 The fatty acid composition of the serum chylomicrons and adipose tissue of children with cystic fibrosis of the pancreas. J Pediatr 60:394

23. Kyriakides EC, Beeler DA, Edmonds RH, Balint JA 1976 Alternations in phosphatidylcholine species and their reversal in pulmonary surfactant during essential fatty-acid deficiency. Biochim Biophys Acta 431:399

24. Lloyd-Still JD 1983 Growth, nutrition, and gastrointestinal problems. In Lloyd-Still JD (ed), Textbook of Cystic Fibrosis. John Wright, PSG Inc Boston, pp 227-26

25. Lloyd-Still JD, Johnson SB, Holman RT 1981 Essential fatty acid status in cystic fibrosis and the effects of safflower oil supplementation. Am J Clin Nutr 34:1

26. Mischler EH, Parrell S, Farrell PM, Odell GB 1982 Comparison of effectiveness of pancreatic enzyme preparations in cystic fibrosis. Am J Dis Child 136:1060

27. Radin NS 1979 Preparation of lipid extracts. Meth Enzymol 14:245

28. Rivers JPW, Hassam AG 1975 Defective essential-fatty acid metabolism in cystic fibrosis. Lancet 2:642

29. Rogiers V, Crokaert R, Vix H 1980 Altered phospholipid composition and changed fatty acid pattern of the various phospholipid fractions of red cell membranes of cystic fibrosis children with pancreatic insufficiency. Clin Chim Acta 105:105

30. Rogiers V, Dab' I, Crokaert R, et al. 1980 Long chain non-esterified fatty acid pattern in plasma of cystic fibrosis patients and their parents. Pediatr Res $14: 1088$

31. Rogiers V, Vercruysse A, Dab I, et al. 1983 Abnormal fatty acid pattern of the plasma cholesterol ester fraction in cystic fibrosis patients with and without pancreatic insufficiency. Eur J Pediatr 141:39

32. Rosenlund ML, Selekman JA, Kim HK, et al. 1977 Dietary essential fatty acids in cystic fibrosis. Pediatrics 59:428

33. Sanders RL 1982 The composition of pulmonary surfactant. In: Farrell PM (ed) Lung Development: Biological and Clinical Perspectives. Academic Press, Inc, New York, pp 193-210

34. Winer BJ 1977 Statistical Principles in Experimental Design, 2nd ed. McGrawHill, New York, pp 199-214

35. Wood RE, Boat TF, Doershuk CF 1976 Cystic fibrosis: state of the art. Am Rev Respir Dis 113:833 